Philosophy and Progress: Vols. LVII-LVIII, January-June, July-December, 2015 ISSN 1607-2278 (Print), DOI : http://dx.doi.org/10.3329/pp.v57il-2.31207

\section{ENVIRONMENT, GLOBALIZATION AND CULTURE}

\section{Sreetama Chakraborty ${ }^{*}$}

One of the burning issues of contemporary society is globalization, the currents of which emerged especially with the advent of industrialization and technological innovations. In the twenty-first century, modern society has doubtlessly accepted globalization as part of our own culture, but it cannot be shunned away that globalization as a strong force in revolutionizing the mechanisms of the world has largely succeeded in privileging consumerism. Hence, in short, it can be said that globalization, fueled by consumerism are the gifts of modern day culture. If this is the scenario, then in the climax of mechanization, technocratization and globalization, environment and natural elements are sidelined and treated as separated from our culture. Environmental discussions ought not to be separated from our cultural aspects, values and beliefs; rather, our culture ought to promote environmental

\footnotetext{
Assistant Professor, Department of Philosophy, Belda College, Vidyasagar University, West Bengal, E-mail: sreetamaphil@gmail.com
}

values, which resultantly promotes ethical foundations for our society. Ethics rests on the idea of living a morally good life. It also gives rise to a sustainable ethics, an ethics that helps in sustaining and taking care of future generations too. The attempt in this paper is to promote an ethics of the environment in all our living and cultural engagements by peeping through the lenses of feminism and a biocentric ethical framework, which are the cooperating tools for a sustainable globalization.

\section{I}

Let me begin defining what globalization means. It is generally defined as a situation/position where there is an intermingling of international resources along with sharing of thoughts, ideas, beliefs and practices. It helps in generating economy, public policies and strategies in the large-scale interests of the individuals. It also helps promoting global understanding in matters relating to trade and commerce, environmental resources and other commodities relating to wants, necessities and others. On the one hand, where the arrival of globalization is a blessing, on the other it a threat to the global world. It is because in the pretext of benefitting and securing human future, globalization in the recent ages has become a threat to modern human culture. Globalization supported by high-speed technological innovations led to the overuse and destruction of natural resources and ecosystems in a heightened manner. Let me recall in this connection the words of Christopher Manes (1990) when he says, "industrial society may indeed be the most deleterious and unsustainable economic system the world has ever seen, since it constantly eats into the ecological systems on which it depends." Manes suggests that industrial way of life must not be seen always as a necessity, but can be considered as only a choice, a choice to choose the less destructive routes for civilization and reshaping our cultures keeping in consonance human sympathy towards nature. 
Globalization has deep-rooted influence on our culture. Technology has blessed humanity by the aid of which it is now becoming more and more possible to adopt clean, green and environment friendly conditions for the common person, but at the same time, it is using the environment for building up an environmental friendly condition in all human space and cultures. We see that consumerism that is deeply rooted in the conscience of man allows no space to nurture and culture the values and ideals of environmental ethics and morality. Consumerism promotes an extension of the unlimited wants and desires of man by sensualising their desires, creating extra luxurious needs in the minds of man and making them addict to buy goods unrestrictedly in even greater amounts. Therefore, environmental approaches stand forth as a criticism to consumerist behaviors. Jean Baudrillard claims that human purchases of products have turned out to be their 'characteristic signs of happiness'. (2000, p. 70) It reflects human innermost desires to consume more and find fulfillment in unnecessary consumption. This scenario is a picture of the hyper real. In addition, this overconsuming tendency has resulted man to recognize it as a social event, which furthermore features a capitalist society.

The addiction of overconsumption that grew with the currents of globalization has succeeded in snatching away humans' innate urge from being a part of nature, and harmed humans' way to live a sustainable life. In all this, i.e. the tendency of consumerism is ruled by culture. Our culture influences our social status, ways and procedure of living a healthy life and if human culture advocates a broader perspective, then the mind develops and broadens. However, if culture proposes narrow perspective, then the individual begins to act from selfishness and self-centeredness. (Haenn \& Wilk, 2006) It is for this reason, in all our traditions and customs, culture is sharply distinguished from nature and its processes. J. S. Mill argues that nature is opposed to culture mainly because nature is not artificial, every occurrences in nature is without human intervention. On the contrary, culture can be called an art, a product that results from the agency of man. Mill goes on adding that man is formed out of nature and becomes what they become by culture. It is because of the consumerist and overgrabbing attitude in man that ultimately results in non-contentment and therefore leads to crime, violence and corruption against nature. Since ages, humans depend on the other human and each species depend on the other species for its survival. However, contemporary society seems to lose its soul and suffer due to lack of moral values and principles of caring and respect. The principles of care and respect are extremely significant while extending moral concerns to species beyond humans. Let me now point out that man/nature relationship has been addressed in several prospects ranging from feminist philosophy to ethics of land sustainability that played extensive roles in building up the notions of care and respect and so on.

\section{II}

Several environmental stances that were once considered as total seems short in addressing the multidimensional sentiments ruling the people of various gender identities. In the contemporary scenario, where consumerist corporate culture has significantly blanketed human culture, making it thoroughly individualistic and self centered, environmentalism as a strong and powerful force in the feminist discourse attempts to regain all the lost sensibility between man and nature. Contemporary political issues concerning the rage of cultural, economical and financial wars between borders, issues of welfarism and unemployment, immigration and health care has never been so drastic and severe until the unveiling of the 
continuous use of human induced environment unfriendly techniques in our social systems. In socializing the human self on the one hand and in making an everyday interaction with the very contemporary issues relating to injustices in health, war, human development, environmental has undoubtedly put strain in our multicultural democracies. Our relationships with the environment exist in an instrumental form, which we largely call it as anthropocentric. Alternatively, at large when it comes to a bio-centric understanding, then what is expected is to value the biotic community for the fact that it makes us survive healthily and happily. Eco-feminism, as against the one centered instrumentalist approach, is a severe and thorough going idea providing answers to all kinds of gender biasedness existing in today's society and politics. In this section, I shall give an outline of the multi directive arguments for reconsidering the sentiments of the environmental feminists' position in the age of contemporary politics and society. Ecofeminists has two primary positions - to attack the conventional masculine dominion towards nature, and to urge for adoring the notions of care, respect and so on.

What appears in most of the literatures is that ecofeminism radically establishes and connects the domination of women with that of nature. They argue that human's mentality towards destruction of environmental objects is due to the result of oppression and subjugation adopted by men in patriarchal western society. Nature as carrying the feminine characteristics were always thought of as submissive and silent and therefore made an object of domination, subjugation and oppression. Nature has been victimized; their fruit has been reaped without showing any gratitude to its lifelong contribution. Invariably linking the two radically distinct entities - women and the environment, the environmental feminists confronts certain issues such as race, gender, class, sex and nature. Eco feminism as a movement towards social justice claims to examine the socio economic environmental problems from a broader lens of feminism. What happens commonly in most of the South Asian countries is that the destruction of natural resource sources and the regular occurrence of natural disasters have made women the worst sufferers. In times of scarcity, the rate of gender discrimination increases like anything resulting in the decline of women's health, poor attendance of girls in schools, lack of nutritious food during maternity and so on. The eco feminists lay their basic premise that stereotypical gender discrimination in our societal structure in terms of racism, sexism and classism has played an effective role in treating nature simply as an object to be used for. In the opinion of many feminists, it is the historic domination of women by men from which all other power relations, dominations, and class divisions flow. They hold that it is mainly the dualistic mode of class relations functioning in our societal system, which causes man's destructive attitude towards nature and its resources. In all the dualistic model of class relations such as male/female, masculinity/feminity, reason/emotion, active/passive, civilized/inferior, human/ animal, it is the former which symbolizes men or the most powerful class and the latter is a representation of a more submissive, more soft nature who are entitled to be suppressed and dominated by the former class. Karen J. Warren in her article "Ecological Feminist Philosophies: An Overview of the Issues" makes a mention of Rosemary Radford Ruether, who in her 1975 work New Women/New Earth wrote: 'Women must see that there can be no liberation for them and no solution to the ecological crisis within a society whose fundamental model of relationships continues to be one of domination. They must unite the demands of the women's movement with those of the ecological movement to envision a radical reshaping of the 
basic socioeconomic relations and the underlying values of this (modern industrial) society.” (Warren, 1993) Yayo Herraro notes that it is "globalization for the sake of profit has led to "the poverty of women and indigenous cultures, who are the first victims of the destruction of nature'.” The best ecofeminist example can be cited from Indian context in referring to the Chipko movement where thousands of women protested against the cutting down of trees in valleys which signified their source of livelihood and worked out with the following slogan. Embrace our trees//Save them from being felled//The property of our hills//Save it from being looted. I agree with the view that most feminists hold while relating the two contingent entities - women and environment, that historically women have been seen more responsive towards environmental problems because both are seen as weak, inferior and an object to be lured and used only. However, many feminists hold the opinion that it is not men per se who is destructive, rather it is the patriarchy working in the minds of the people that is causing destruction. These entire crises causing human society and the environment can be controlled with the aid of embracing the elements of care and nurture towards the other.

The next concern of the ecofeminists is to humanize those principles for which a woman is always oppressed and treated inferior. The elements of care, respect, love, sympathy, adoration, restoration and understanding which a woman has, must not be seen as women's properties, but must be considered as human properties, so that it goes beyond the feelings of dominion and supremacy, which will definitely be a guiding impetus in extending human soft naturedness towards nature. They claim for uprootment of gender biasedness attached with these sympathetic terms, and make a call for gender neutrality of these terms. With the mutual sharing of these feelings, each of us must extend our concerns beyond human beings, embrace the family of environment as whole, and consider humans to be a part of the natural processes. Similar sympathetic considerations also arise in the case of an ecological ethical perspective.

\section{III}

Let us now consider the case of biocentrism where humans are treated as not apart from nature, but as one among the earth community. It is seen that environmental ethics challenges the separation of man/nature or nature/culture even in many other discourses. In the context of man/nature, J. L Baird Callicott writes, "Nature as Other is over .... The modern picture of nature is false and its historical tenure has been pernicious. A new dynamic and systemic postmodern concept of nature, which includes rather than excludes human beings, is presently taking shape." Callicott hopes to cure us from the "sharp dichotomy between man and nature," which has too long been a feature alike of religion and philosophy, "both wellsprings of the Western intellectual heritage ... . We are therefore a part of nature, not set apart from it.”

Callicott is a follower of Aldo Leopold and always aimed to bring together humans and nature. Not unlike Leopold, he argues that humans are a part of environmental culture and its other processes. Looking at the destructive evils of modernity and the crisis that the environment is subject to, Callicott claims that Nature is no longer to be treated as the other. It ought to be respected and cared for, but not as a means to attaining disastrous ends. However, with the evoking tendency of consciousness in man, ethical morality is taking shape, Callicott maintains. A more radical shape took turn during the period of Aldo Leopold. Leopold belonged to a period when people were glittering with the benefits of globalization; it resulted in consumerism, spreaded throughout their nerves and 
veins and mixed up in their cultures. It was during that time when Leopold felt the need for a long term planning in environmental discipline. He then felt that environment should be a platform, which must be the concern of humanity. Planet world must be considered a community as a whole in which humanity forms only a part and share equal value with other entities including land, water, air, species, and insects and so on. Callicot's name primarily appears in defending Leopold's land ethical approach. In Callicot's view, an individual is not only a member of his society but also of the world community and of whole of the biotic community. Therefore, it is the duty of each member to preserve and protect the community in which it belongs. Humans, being a part of the whole of land community, ought to respect and guard land, as an entity worthy of respect in itself. However, Callicot has to face severe criticisms due to adopting a communitarian approach and preferring biotic community, his approach turns out to be distinctive in the claim that community feeling arises with the feeling of duty and responsibility for the entities of higher interests and of the biotic community and the land. Callicot writes:

We may expect to find that the scope and specific content of ethics will reflect both the perceived boundaries and actual structure or organization of a cooperative community or society. Ethics and society or community are correlative. This single, simple principle constitutes a powerful tool for the analysis of moral natural history, for the anticipation of future moral developments... Most educated people today pay lip service at least to the ethical precept that all members of the human species, regardless of race, creed or national origin, are endowed with certain fundamental rights which it is wrong not to respect. According to the evolutionary scenario set out by Darwin, the contemporary moral ideal of human rights is a response to a perception - however vague and indefinite - that mankind world-wide is united into one society, one community, however inderetminate or yet institutionally unorganized. (1987, p. 176)

Callicott's words clearly reflects that since ages this feeling of unitedness has bonded humanity with the non-human entities, and though current waves of modernity might wipe off this realization, yet rebuilding or reshaping this lost urge would not be too difficult for human species. He makes a call for man-nature's natural relationship when he writes that humans ought to "reaffirm our participation in nature by accepting life as it is given without a sugar coating. . . . accept and affirm natural biological laws, principles, and limitations in the human personal and social spheres." (Callicot, 1989, p. 33) This aspect of human self in the process of realization has a strong impact on environmentalism, and theories developed resultantly such as the 'deep ecology,' also called the ecosophy movement that interlinks humans' life with what environmentalism demands. Deep ecology prominently appears in one of Arne Naess'seminar articles, 'The Shallow and the Deep, LongRange Ecology Movement', where he talks of a reform movement, a prospect of connecting the self with the larger cosmos by stressing on how a self realizes its continuity with nature in spirit and out. In Naess' words, 'We need an expanded sense of self, one in which acting on behalf of others and the ecosphere is ultimately acting in terms of "enlightened self-interest" and not out of some sense of moral obligation or duty, or even the rights of others perceived as separate from our own interests.' (Macy, 1990, p. 62) Deep ecology strives for wider self-identification with the whole, an expansion of the smaller human self and transcending of the materialist cultural impacts on human life. 


\section{IV}

The above discussion reflects the impacts of globalization on our environment and how the perspectives of care, respect and realizations in different ethical domains have left their imprint in suggesting a holistic and sustainable approach. Therefore, considering the present day cultural crisis faced by humanity in all its aspects, the major question arises is if culture and nature exist as opposed to each other, then how can environmental rights be strongly protected. It is because vibrations for advocating an ethics of the environment are advocated by our culture only. Rights are strong viable forces that work with the consent of members in a society. If rights have to have in favor of nature and environment, then there must be a cultural set up. In addition, that cultural framework must not be biased upon narrowed prejudices and society based norms advocating more anthropocentric norms and principles. Experiences reveal that environment has always been de-spirited and neglected in our main course activities. The result is an increase in environmental degradation, which is directly affecting the human species and if it is not checked right now, then it would become dangerous for future generations to survive in this planet. It has to be extended to the extent that culture must promote nature and environmental ethics. We cannot disseminate culture from the environment and its content.

Nature and environment functions independent of culture. However, no culture is independent of nature. Culture is constructed out of natural and environmental conditions. It may be that the concept of culture varies from society to society, it has no fixed laws. What is good for one culture may be wrong for the other culture. True that culture always remains in the verge of progressing, but does culture progress keep in concern the question of sustainability? Most of the times, culture always remains separated from the question of sustainability. It is culture which enables the platform for environmental sustainability and addresses multi dimensional issues like poverty, well being, peace, social cohesion, and developmental policies.

Sustainability is actually a holistic approach. It helps developing an ethics, where people are not guided by the misleading trends of consumerism, but do care for the future generations. Perpetuating consumerism increases luxurious consumption to the extent that people acquire things, not impelled by need, but by false desires and leads man towards adopting a fake cultural framework. In addition, media, advertisements and company agencies promote new brands and products, instilling in the minds of consumers to immediately grab the product. However, sustainable ethics ensures people to accommodate nature in the periphery of cultural discourses and allow further generations to reap the benefit of its success. Sustainability is a feeling for preservation which, when transformed and brought into action, yields extremely beneficial results. Even then, the principle of sustainable development has also witnessed threatening results. The idea of sustainability was born as a reactionary to the present cultural crisis fueled by rampant industrial and technological misuse with the environment. However, the tragedy lies in the fact that the same industrialization and scientism is used to promote sustainability. Since the second half of twenty-first century, environment has become one of the chief discourses in contemporary modern day society mainly because concern for environmental issues transcends all kinds of regional/national/ international boundaries and makes people think in terms of one race sharing a common space and a common planet to live in. Therefore, our aim for a sustainable society must be a culture driven one. In collaboration with the United Nations Development agenda, several ways of culture driven 
sustainability has come into picture, such as integrating traditional knowledge schemes and practices in sustainable environmental schemes, promoting inter cultural dialogue to stop social cohesion and address development and so on. Culture and built environment are always intertwined together. However, the idea of culture is not a concrete one, nor the idea of built environment. In order to stop the hazards of modern science and technologies, we must built developmental prospects in consonance with human culture, so that the future generations can reap its fruit without any danger. And what is it that remains permanently sustainable? It is doubtlessly the cultivation of human-environmental values in man, which can make progress towards a healthy and sustainable ethical development. It is seen that feminism's advocacy of the gender neutral qualities such as care, sympathy, love, admiration and the biocentric environmentalists' ideas of universal communitarianism reflects that the spirit of sustainable development lies inward. Developments might occur in exterior, green policies might be adopted worldwide, but unless the green value sense evolves in human hearts, sustainability becomes fruitless. Ethical sustainability therefore leaves open the platform for a universalizable identity beyond race, gender and species distinctions.

Key Words: Environment, Globalization, Culture, Sustainable development, Feminism.

\section{References}

1. Callicot, J. Baird. (1987). The Conceptual Foundations of the Land Ethic. In Companion to a Sand County Almanac, Madison: University of Wisconsin Press.

2. -------. (1989). Animal Liberation: A Triangular Affair. In In Defense of the Land Ethic: Essays in Environmental Philosophy. Albany: State University of New York Press.
3. Haenn, Nora and Richard R. Wilk, (eds.) (2006). The Environment in Anthropology: A Reader in Ecology, Culture and Sustainable Living. New York \& London: New York University Press.

4. Lane, Richard J. (2000). Jean Baudrillard, London \& New York: Routledge.

5. Macy, Joanna. (1990). The Greening of the Self. In Dharma Gaia: A Harvest of Essays in Buddhism and Ecology, ed. Allan Hunt Badiner, Berkeley: Parallax Press.

6. Manes, Christopher. (1990). Green Rage: Radical Environmentlaism and the Unmaking of Civilization. Boston: Little Brown \& Company.

7. Naess, Arne. (1989). Ecology, Commuity and Lifestyle. Ed. \& trans. David Rothenberg, Cambridge; Cambridge University Press.

8. Warren, Karen J. (1993). Ecological Feminist Philosophies: An Overview of the Issues. In Michael E Zimmerman, J. Baird Callicott, George Sessions, Karen J. Warren \& John Clark (eds.), Environmental Philosophy: From Animal Rights to Radical Ecology (pp. 253-267). Englewood Cliffs, NJ: Prentice Hall 